Original research article

\title{
Reasons for unfinished nursing care from the perspective of nurses from regional and university hospitals
}

\author{
Elena Gurková ${ }^{1}$, , Daniela Bartoníčková ${ }^{1}$, Zdeňka Mikšová ${ }^{1}$, Monika Labudíková ${ }^{2}$, \\ Daniela Chocholková ${ }^{3}$ \\ ${ }^{1}$ Palacký University in Olomouc, Faculty of Health Sciences, Department of Nursing, Olomouc, Czech Republic \\ ${ }^{2}$ University Hospital Olomouc, Department of Hemato-Oncology, Olomouc, Czech Republic \\ ${ }^{3}$ University Hospital Olomouc, Department of Anesthesiology and Intensive Care Medicine, Olomouc, Czech Republic
}

\begin{abstract}
Aim: The main aim of the paper is to examine the differences in reasons for unfinished nursing care according to the type of hospitals and wards. The work also intends to investigate the relationship between the reasons for unfinished nursing care and nurses' job satisfaction. Design: Cross-sectional correlation study.

Methods: The sample consisted of 371 nurses working in internal medicine and surgical disciplines of four selected hospitals in the Olomouc region. The Czech version of the MISSCARE Survey questionnaire was used to collect data, containing 61 items divided into three areas - work-related factors, activities of unfinished care and reasons for unfinished care. The reasons for unfinished nursing care were operationalized in the MISSCARE Survey by domains, such as human resources, material resources and communication. The data collection was held between May and September 2020. ANOVA test and Pearson correlation coefficient were used to analyse the data. Results: Human resources and staffing were rated as the most important reasons for unfinished nursing care. Significant differences between university and regional hospitals were found in the human and material resources. A positive correlation was found between the number of patients in the last shift and the significance of reasons in human and material sources and communication. A negative correlation was found between the nurses' satisfaction with their current position, with the role as a nurse, with the teamwork, and reasons for unfinished nursing care.

Conclusions: A deeper analysis of processes contributing to the prevalence of missed nursing care can help better understand the barriers in providing a complex nursing care and can implement effective interventions into practice.
\end{abstract}

Keywords: Acute care; Instrument; MISSCARE Survey; Missed nursing care; Reasons

\section{Introduction}

Unfinished nursing care is characterized as any element in the necessary care of patients that was partially or completely excluded while providing care. It includes the errors of omission or omitted care that can endanger patients' life (Jones et al., 2015). The errors of omission are inconsistent with the international standards of patient safety and quality of provided care (Cho et al., 2016; Jones et al., 2015). It has been proved that 14-96\% of all errors in treatment tend to be caused by omission from nurses (Kalisch et al., 2011a). In European countries, it is stated that, on average, 3.6 out of 13 nursing activities are not performed (Ausserhofer et al., 2014). The prevalence of unfinished care in EU and OECD countries is rather high, ranging between 55 to $98 \%$ (Jones et al., 2015).

The conceptual framework of this paper is the Kalisch model (Kalisch et al., 2009) of missed nursing care. It defines the basic components of nursing care (Kalisch et al., 2009) that were omitted by a nurse. Each component of care was designed based on a long-term qualitative research. Defining the most common reasons for and consequences of unfinished care is a significant part of the Kalisch model. Unfinished care has a negative impact not only on patient safety but also on the quality of care provided (Jones et al., 2015). It is associated with a higher incidence of adverse events, such as patient mortality, falls, nosocomial infections, medication errors and low satisfaction of patients with the quality of care (Kalisch and Williams, 2009). The model also defines the consequences of unfinished care influencing the nurses themselves - negative impact on nurses' job satisfaction, burnout and nurse retention. Based on this conceptual framework, the MISSCARE Survey tool was developed and tested (Kalisch and Williams, 2009). It is currently one of the most frequently used tools in this area. The MISSCARE Survey has already been pilot tested in the Czech socio-cultural context (Zeleníková et al., 2019). Over the last decade, several self-assessment tools have been developed to assess missed care, and their development con-

\footnotetext{
* Corresponding author: Elena Gurková, Palacký University in Olomouc, Faculty of Health Sciences, Department of Nursing, Hněvotínská 976/3, 77515 Olomouc, Czech Republic; e-mail: elena.gurkova@upol.cz http://doi.org/10.32725/kont.2021.026 
tinues. In this research, however, we decided to use only a specific part of the most frequently used MISSCARE Survey tool, focusing on mapping the reasons for unfinished care.

The number of publications related to investigating reasons for a great prevalence of unfinished nursing care has been growing intensively in recent decades (Griffits et al., 2018; Jones et al., 2018). Many of them are based on international, multicentre projects, such as RN4CAST; RANCARE; MISSCARE STUDY GROUP, and on a great number of other national research activities.

RN4CAST and MISSCARE STUDY GROUP projects have examined unfinished care as a mediator between the systemic and organizational factors (e.g. aspects of work environment, staffing) and the quality of nursing care. The unfinished care has been confirmed as a key factor to develop adverse events and as an indicator of quality in nursing care (Aiken et al., 2018; Ball et al., 2018; Griffiths et al., 2018). The RANCARE project that the Czech Republic was involved in focused - through an international comparative approach - on analysing the conceptual, organizational, methodological and ethical aspects of unfinished care, on defining the interventions to influence it, as well as the development of educational programmes in this area.

Factors contributing to unfinished care cannot be reduced only to the problem of limited nurse staffing or material resources. Factors related to the work environment are also at the forefront (Aiken et al., 2014, Ausserhofer et al., 2014, Schubert et al., 2008, 2013). In connection with the global shortage of nurses, there are situations where unfinished nursing care becomes a common part of clinical practice and remains unrecognized by the personnel (Bagnasco et al., 2017). If nurses do not point out this phenomenon, there is a risk that it becomes a kind of norm. The literature revised by Kalánková et al. (2019) identified certain reasons that fall into certain areas. The organizational factors are the first area. The influence on unfinished care was examined within the organizational factors when disrupting the daily routine (Mgbekem et al., 2016). This area can become a significant factor affecting the prevalence of unfinished care during the COVID-19 pandemic. The increased workload, a high number of overtime hours, changing wards with a short time for training, transformation of wards etc., are factors that can greatly affect the nurse's daily routine. Staffing is another area. In connection with this area, a shortage of nurses (Henderson et al., 2017) and support and/or administrative personnel has been discussed (e.g. Maloney et al., 2015). Other areas that were identified included, insufficient material support; communication and relationships (e.g. Cho et al., 2016), as well as insufficient support for nurses by nurse managers (e.g. Vryonides et al., 2015). Finally, the characteristics of patients are also important, especially in the acute deterioration of a patient's condition and an unexpected increase in the number of patients (e.g. Bragadóttir and Kalisch, 2018).

In the pilot study performed in the Czech Republic and in Slovakia in 2019, staffing was identified as the main reason for unfinished nursing care (Zeleníková et al., 2019). Other reasons that can contribute to missed care need to be further revealed (Dutra et al., 2019). It was proved that the most common reasons abroad include: insufficient human, material and technical resources, insufficient number of specialists, and decline in teamwork within a nursing team, as well as in communication with patients (Bragadóttir and Kalisch, 2018; Cho et al., 2015; Kalisch et al., 2009; Moreno-Monsiváis et al., 2015).

The main goal of the work was to find the differences in reasons for unfinished nursing care according to the type of hospitals and wards. The study also included an examination of the relationship between the reasons for unfinished nursing care and nurses' job satisfaction.

\section{Materials and methods}

\section{Sample}

All university hospitals $(n=1)$ and regional hospitals $(n=7)$ within the Olomouc region were invited to participate in the research study. Only 4 hospitals agreed to participate in the research. The sample was composed of one university hospital and three regional hospitals that provided a written consent with the research. General and practical nurses from these hospitals were addressed through the method of convenience sampling, and those nurses were included in the sample if (a) they worked on standard surgical or internal medicine wards; (b) they provided care to adult patients; (c) they worked shifts. Nurses were not included if (a) they worked on paediatric and/or gynaecology-obstetrics wards, (b) they worked as managers. For statistical purposes, hospitals were divided into two groups - university hospitals (one hospital with more than 1000 beds) and non-university, regional hospitals (two hospitals with fewer than 300 beds, and one with more than 300 beds). Individual wards were further subdivided into two groups: the surgical, and the internal medicine wards. Within the first group, surgical, traumatological, orthopaedic and oto-rhino-laryngological wards were addressed. The second group was made up of internal medicine, neurological, geriatric, oncological and palliative care wards. The researcher was present in each selected hospital and always explained the purpose of the research to head nurses from the ward where the research was performed. The questionnaires were distributed to general and practical nurses working on the selected wards. Their participation in the study was on a voluntary basis. The data were gathered between May and September 2020, which was between the first and second wave of the COVID-19 pandemic in the Czech Republic. In total, 554 questionnaires were distributed. Of these, 371 were returned, and the total return rate of the questionnaires was $66.49 \%$. The characteristics of the selected sample are described in Table 1.

\begin{tabular}{lrr}
\hline Table 1. Sample characteristics & & \\
\hline Characteristics & Number & $\%$ \\
\hline Gender & & \\
$\quad$ female & 343 & 92.5 \\
$\quad$ male & 18 & 4.9 \\
\hline Work position/role & & \\
$\quad$ general nurse & 241 & 66.2 \\
$\quad$ practical nurse & 56 & 15.4 \\
$\quad$ specialized nurse & 67 & 18.4 \\
\hline Highest education level & & \\
$\quad$ SZŠ/VOŠ & 277 & 77.2 \\
$\quad$ Bc/Mgr/PhD & 82 & 22.8 \\
\hline Shifts & & \\
$\quad$ day/morning & 112 & 30.4 \\
$\quad$ night & 8 & 2.2 \\
$\quad$ changeable & 246 & 66.7 \\
$\quad$ others & 3 & 0.8 \\
\hline Wards & & \\
$\quad$ surgical & 160 & 44.0 \\
$\quad$ internal medicine & 204 & 56.0 \\
Hospital type & & \\
$\quad$ university & 214 & 57.7 \\
regional & 157 & 42.3 \\
\hline
\end{tabular}




\section{Data collection method}

The MISSCARE Survey questionnaires were used as the data collection method (Kalisch and Williams, 2009). The Czech version of the questionnaire, created by the team of authors of the University of Ostrava (Jarošová and Zeleníková, 2017), was used in an original and the Czech version with the consent of authors. The MISSCARE Survey questionnaire (Kalisch and Williams, 2009) was created in the USA to assess the missed nursing care. It is currently one of the most widely used tools in this area. It is composed of three parts. The first part contains 20 items focused on demographical issues and work characteristics. The second one (part A) includes 24 items focused on unfinished nursing care. The items are rated on the 5-point Likert scale ranging from "always omitted" to "never omitted". The third part (part B) is composed of 17 items investigating the reasons for unfinished nursing care. The items are rated on the 4-point Likert scale ranging from "no reason" (1) to "a serious reason" (4). In accordance with the set goals (examining the reasons for unfinished care), we have focused, in the manuscript, on analysing the items in part B. We used questions from the first part of the questionnaires associated to assessing the satisfaction with teamwork, with the role of a nurse, with the current job position, with working overtime and with the number of patients in the last shift. The satisfaction with the job position, team work and the role of a nurse were evaluated on the 5-point Likert scale ranging from 1 "very dissatisfied" to 5 "very satisfied", with a higher score always meaning a higher level of nurses' satisfaction. The data were analysed as a part of a project that comprehensively examined the relation between the work environment and unfinished nursing care (IGA_FZV_2020_001). In the submitted manuscript, partial outcomes from the project are mentioned.

\section{Ethical aspects}

The research protocol was approved by the Ethic Committee of the Faculty of Health Sciences of Palacký University in Olomouc (protocol number: UPOL-1689/1040-2020).

\section{Data analysis}

The method of descriptive and inductive statistics was used for statistical data analyses. The quantitative variables were evaluated by the arithmetic mean, standard deviation, absolute frequency $(N)$, relative frequency (\%). Normality of quantitative data was verified using Shapiro-Wilk normality test. Parametric tests (one factor ANOVA tests) were used to evaluate the differences, and the principal component analysis method was used to evaluate the factor structure of part B. The mutual correlation of the quantitative variables was determined using the parametric Pearson's correlation analysis. A $p$-value $<0.05$ was taken to indicate statistical significance for all comparisons. IBM SPSS Statistics for Windows, Version 20.0 statistic software was used for statistical analysis.

\section{Results}

\section{Results of the exploratory factor analysis MISSCARE Survey, part $B$}

The first step was to determine the correlation between items in order to check the suitability of items for the factor analysis. The tightness of correlation among all 17 items was higher than 0.3 , which means that there were no low cross-correlations found for any of the items, on the basis of which the items should be excluded from the analysis. In the correlation matrix, $100 \%$ correlation coefficients were higher than the required value of 0.3. Kaiser-Meyer-Olkin statistics (KMO) and Bartlett's test for sphericity were further used to assess the suitability of the factor analysis. Higher KMO values indicate the suitability to use the factor analysis. In our case, the value of total KMO 0.927 exceeds the recommended value of 0.6 . In our case, the significance value of Bartlett's test for the factor analysis was sufficient $\left(\chi^{2}=4000,23 ; \mathrm{df}=136 ; p<0.0001\right)$. The level of KMO was further assessed particularly for individual items, in $\mathrm{KMO}$ items the value should be over 0.5. KMO, for individual items it was assessed in so-called anti-image matrix, i.e. in the matrix of negative partial correlation coefficients. The minimal level of KMO items was 0.868 , the maximal was 0.967 . Due to meeting all the prerequisites (correlation of individual items over 0.3 , KMO significant total value and $\mathrm{KMO}$ for individual items, significant Bartlett's test for sphericity), the data were suitable for the factor analysis.

The number of factors was determined on calculating the eigenvalues. The eigenvalues were higher than 1.0 in all 3 components (factors). The first component (Factor 1) explained $24.15 \%$ of variability contained in 17 variables. The second factor (Factor 2) explained $23.30 \%$ of variability in items. The third factor (Factor 3 ) explained $23.32 \%$ of variability. All three factors together explained $69.77 \%$ of variability. Furthermore, it has been determined, by means of calculating factor loadings, which items saturate individual factors, i.e. which items belong to which factor. After Varimax rotation of factors, factor loadings were divided into three factors (Tables 2, 3):

- Factor 1 (Communication) saturates 6 items: 11, 12, 13, 14,15 and 16.

- Factor 2 (Human sources, staffing) saturates 6 items: 1, 2, $3,4,5$ and 17.

- Factor 3 (Material resources) saturates 5 items: 6, 7, 8, 9 and 10 .

Of these, items 11, 15 and 8 were equally saturated by two factors (Factor 1 and Factor 2), and item 17 was equally saturated by two factors as well (Factor 1 and Factor 2). Results of the factor analysis led to a three-factor model after excluding items 11, 15, 8 and 17 that were saturated by more factors (cross-loadings). These four items were loaded on several different factors and could not therefore be assigned to one single factor. The Cronbach's alpha coefficient of individual factors was sufficient (Table 2). Excluding items saturating more factors (cross-loadings) would not lead to significant changes in values of the coefficient (Table 2). For this reason (and due to insufficient score of item communality after extraction) the items were not excluded from the analysis.

The results of the descriptive analysis of the MISSCARE questionnaire part $\mathrm{B}$ show that the most significant reason for missed nursing care reported by general and practical nurses included the unexpected increase in number and severity of patients' conditions on wards, emergency situations in patients and insufficient staffing (Table 2). The highest score was reported in human resources and staffing (Table 2 ).

\section{Differences in reasons for missed nursing care according to the type of hospitals and wards}

Differences in perception of reasons for missed nursing care were identified in human and material resources. No significant reasons were revealed in communication. Human and material resources were more important for general and practical nurses working in regional hospitals, compared to nurses working in university hospitals (Table 4). No differences to the perceived reasons for missed nursing care were identified 
Table 2. Descriptive statistics, internal consistency, and factor structure of MISSCARE Survey questionnaire, part B

\begin{tabular}{|c|c|c|c|c|c|}
\hline Item & $N$ & Mean & $\pm \mathrm{SD}$ & $\begin{array}{c}\text { Factor } \\
\text { loadings }\end{array}$ & $\begin{array}{c}\text { Cronbach alpha } \\
\text { coefficient }\end{array}$ \\
\hline \multicolumn{6}{|l|}{ Factor 1 (Communitation) } \\
\hline 11. Lack of back up support from team members* & 346 & 2.26 & 1.02 & 0.654 & \\
\hline $\begin{array}{l}\text { 12. Tension or communication breakdowns with other } \\
\text { ancillary/support departments }\end{array}$ & 344 & 2.27 & 0.93 & 0.788 & \\
\hline $\begin{array}{l}\text { 13. Tension or communication breakdowns within the nursing } \\
\text { team }\end{array}$ & 350 & 2.32 & 1.02 & 0.828 & \\
\hline $\begin{array}{l}\text { 14. Tension or communication breakdowns with the medical } \\
\text { staff }\end{array}$ & 350 & 2.42 & 1.017 & 0.811 & \\
\hline $\begin{array}{l}\text { 15. Nursing assistant did not communicate that care was not } \\
\text { provided* }\end{array}$ & 344 & 2.55 & 1.08 & 0.654 & \\
\hline 16. Caregiver off unit or unavailable & 346 & 2.62 & 1.06 & 0.593 & \\
\hline Communication & 333 & 2.41 & 0.85 & & $0.910 ; 0.897^{* *}$ \\
\hline \multicolumn{6}{|l|}{ Factor 2 (Human sources, staffing) } \\
\hline 1. Inadequate number of staff & 354 & 2.95 & 1.04 & 0.725 & \\
\hline $\begin{array}{l}\text { 2. Urgent patient situations (e.g. deterioration of the condition } \\
\text { in a patient) }\end{array}$ & 346 & 2.96 & 1.14 & 0.718 & \\
\hline 3. Unexpected rise in patient volume and/or acuity on the unit & 348 & 2.98 & 1.01 & 0.821 & \\
\hline 4. Inadequate number of assistive and/or clerical personnel & 350 & 2.76 & 0.97 & 0.759 & \\
\hline 5. Unbalanced patient assignments & 348 & 2.40 & 0.92 & 0.679 & \\
\hline 17. Heavy admission and discharge activity* & 349 & 2.65 & 0.98 & 0.625 & \\
\hline Human sources, staffing & 331 & 2.77 & 0.81 & & $0.905 ; 0.878^{* *}$ \\
\hline \multicolumn{6}{|l|}{ Factor 3 (Material resources) } \\
\hline 6. Medications were not available when needed & 349 & 2.41 & 1.06 & 0.770 & \\
\hline 9. Supplies/equipment not available when needed & 350 & 2.44 & 0.99 & 0.777 & \\
\hline 10. Supplies/equipment not functioning properly & 347 & 2.36 & 0.99 & 0.751 & \\
\hline 7. Inadequate hand-off from previous shift & 346 & 2.23 & 0.96 & 0.722 & \\
\hline 8. Other departments did not provide the care needed* & 347 & 2.31 & 0.90 & 0.626 & \\
\hline Material resources & 338 & 2.36 & 0.84 & & $0.886 ; 0.887^{* *}$ \\
\hline
\end{tabular}

Table 3. Differences in factor structure between the Czech and the original version of the MISSCARE Survey, part B

\begin{tabular}{|c|c|c|}
\hline Domain & $\begin{array}{l}\text { Factor structure } \\
\text { of the Czech } \\
\text { version }\end{array}$ & $\begin{array}{l}\text { Factor structure } \\
\text { of the original } \\
\text { American version }\end{array}$ \\
\hline Communication & $\begin{array}{c}6 \text { items* } \\
(11,12,13,14 \\
15,16)\end{array}$ & $\begin{array}{c}10 \text { items } \\
(5,7,8,11-17)\end{array}$ \\
\hline Human resources, staffing & $\begin{array}{c}6 \text { items** } \\
(1,2,3,4,5,17)\end{array}$ & $\begin{array}{c}4 \text { items } \\
(1,2,3,4)\end{array}$ \\
\hline Material resources & $\begin{array}{c}5 \text { items }{ }^{* * *} \\
(6,7,8,9,10)\end{array}$ & $\begin{array}{c}3 \text { items } \\
(6,9,10)\end{array}$ \\
\hline \multicolumn{3}{|c|}{$\begin{array}{l}\text { * Items } 11 \text { and } 15 \text { saturated two factors almost equally (cross- } \\
\text { loading). } \\
\text { ** Item } 17 \text { saturated two factors almost equally (cross-loading). } \\
\text { *** Item } 8 \text { saturated two factors almost equally (cross-loading). }\end{array}$} \\
\hline
\end{tabular}

between surgical and internal medicine wards (Table 4). Weak negative correlations were proved between satisfaction of nurses with their current position, with the role of a nurse, with teamwork at the workplace and the perception of reasons for missed nursing care. The more the nurses were satisfied with their current position, with the role of a nurse, and with teamwork at their workplace, the less they perceived individual areas of the MISSCCARE Survey (human and material resources, communication) as significant (Table 5). A positive relationship was proved between the number of patients in the last shift and the perception of significance of reasons. For nurses, a higher number of patients in the last shift was connected with a higher evaluation of significance of reasons in human, material resources and communication (Table 5). Significant, weak positive correlations were identified between the perception of reasons for missed nursing care and the number of overtime hours in the last 3 months (Table 5). 
Table 4. Differences in the MISSCARE Survey, part B according to the type of hospitals and according to the type of wards

\begin{tabular}{lccc} 
Domain & $\begin{array}{c}\text { University } \\
\text { hospital } \\
(\text { mean, } \pm \text { SD })\end{array}$ & $\begin{array}{c}\text { Regional } \\
\text { hospital } \\
(\text { mean, } \pm \text { SD })\end{array}$ & $p$ \\
\hline Communication & $2.36( \pm 0.85)$ & $2.49( \pm 0.85)$ & 0.195 \\
$\begin{array}{l}\text { Human resources, } \\
\text { staffing }\end{array}$ & $2.63( \pm 0.85)$ & $2.97( \pm 0.72)$ & $<0.0001$ \\
\hline Material resources & $2.22( \pm 0.83)$ & $2.55( \pm 0.83)$ & $<0.0001$ \\
\hline Domain & $\begin{array}{c}\text { Internal } \\
\text { medicine } \\
\text { disciplines } \\
(\text { mean, } \pm \text { SD })\end{array}$ & $\begin{array}{c}\text { Surgical } \\
\text { disciplines }\end{array}$ & $p$ \\
\hline Communication & $2.45( \pm 0.84)$ & $2.39( \pm 0.88)$ & 0.507 \\
\hline $\begin{array}{l}\text { Human resources, } \\
\text { staffing }\end{array}$ & $2.79( \pm 0.77)$ & $2.75( \pm 0.88)$ & 0.658 \\
\hline Material resources & $2.38( \pm 0.83)$ & $2.35( \pm 0.87)$ & 0.721 \\
\hline
\end{tabular}

\section{Discussion}

The aim of the study was to analyse what reasons general and practical nurses perceive as significant in missed nursing care. The research studies that used the MISSCARE Survey focused particularly on analysing the most frequently missed nursing activities, i.e. its part A (Blackman et al., 2015; Bragadóttir et al., 2015; Kalisch et al., 2012; Siqueira et al., 2013; Srulovici and Drach-Zahavy, 2017; Willis et al., 2017). In the first phase of data analysis, the factor structure of part $\mathrm{B}$ in the MISSCARE Survey was analysed. In this part of the survey, we continued in the pilot study of testing the Czech version of the MISSCARE Survey (Zeleníková et al., 2019) in which psychometric properties of the Czech version were tested in a group of $134 \mathrm{Czech}$ nurses. Part A represents an inventory of nursing activities, independent of each other (Kalisch and Williams, 2009). For this reason, only factor structure of part B in the MISSCARE Survey was tested. In our study, we identified three factors representing the main areas of reasons for missed nursing care - human, material resources and communication within the healthcare team. The results of the factor analysis correspond with the previous pilot Czech version (Zeleníková et al., 2019) and other foreign validation studies (Bragadóttir et al., 2015; Kalisch et al. 2011b; Sist et al., 2017). In the Australian study, Blackman et al. (2015) divided 17 items in part B into the following areas - work intensity (items 1, 3, 4, 5); workload predictability (items 2, 16, 17); communication issues (items 12-15) and nursing care resource provision (items 6-11).

In 2020, a new tool for assessing the phenomenon of missed nursing care called Unfinished Nursing Care Survey
(UNCS) (Bassi et al., 2020) was developed, based on the analysis of available tools. The tool was tested on a group of 1,977 nurses from 13 Italian hospitals and has an analogical structure, like the MISSCARE Survey it consists of part A (area of missed nursing activities) and B (reasons for missed nursing care). Based on the explorative and confirmative factor analysis, the authors determined a six-factor structure of part B, and three factors are identical with the factor structure of the MISSCARE Survey (material and human resources, communication). In addition to the above factors, another three factors were identified (priority setting, nurse aides supervision, workflow predictability). The initial intention of Italian authors was to develop a tool that is more focused on the process aspects (setting priorities, the option for nurses to be supervised by their colleagues, involving patients and caretakers) rather than on completing particular tasks (Bassi et al., 2020). The tool was published after the data collection in our study; therefore, we could not use it in our work.

In line with other studies (Bassi et al., 2020; Blackman et al., 2018; Bragadóttir et al., 2015; Kalisch and Lee, 2012), part of which was the analysis of part B of the MISSCARE Survey, it has been confirmed that the insufficient staffing on wards associated with an unexpected increase in the number or severity of patients' conditions on wards belong to the most significant reasons for omitting the nursing activities. Another important finding was the identification of differences in perception of significance of reasons for missed nursing care according to types of hospitals or wards. General and practical nurses working in non-university hospitals consider the human and material resources to be more significant reasons (compared to nurses working in university hospitals). The above results reflect the reality of $C$ zech hospitals, where the smaller regional hospitals face the more significant shortage of nurses. The data gathering was performed between the first and second wave of the COVID-19 pandemic in the Czech Republic. The critical shortage of nursing staff (especially in intensive care) has been frequently discussed in the media in association with the current epidemiological situation in the Czech Republic. The COVID-19 pandemic in the Czech Republic and the associated burden on the system providing the nursing care in hospitals has deepened the problem of the long-term shortage of nurses in the Czech Republic, which was shown in each type of acute hospitals. On the other hand, differences in terms of the types of wards were not statistically significant.

In foreign studies, differences in reasons for unfinished care among various countries were observed (Kalisch et al., 2012), or according to the work position (Bragadóttir and Kalisch, 2018). Kalisch et al. (2012) compared differences in reasons between American and Turkish nurses. It was found that Turkish nurses mentioned organisational barriers (shortage of personnel, communication failures and unavailability of medications in case of need) as more significant reasons for unfinished care.

Table 5. Correlation between domains of the MISSCARE Survey, part B and other variables

\begin{tabular}{lccccc} 
Domain & Overtime & $\begin{array}{c}\text { Satisfaction with the } \\
\text { current posi-tion }\end{array}$ & $\begin{array}{c}\text { Satisfaction with the } \\
\text { role of a nurse }\end{array}$ & $\begin{array}{c}\text { Satisfaction with the } \\
\text { teamwork }\end{array}$ & $\begin{array}{c}\text { Number of patients } \\
\text { in the last shift }\end{array}$ \\
\hline Communication & 0.106 & $-0.121^{*}$ & $-0.133^{*}$ & $-0.250^{*}$ & $0.193^{*}$ \\
Human resources, staffing & $0.180^{*}$ & $-0.235^{*}$ & $-0.218^{*}$ & $-0.245^{*}$ & $0.193^{*}$ \\
Material resources & 0.103 & $-0.149^{*}$ & $-0.145^{*}$ & $-0.238^{*}$ & $0.158^{*}$ \\
\hline${ }^{*} p<0.01$. & & & & \\
\hline
\end{tabular}


In an Australian study, Blackman et al. (2015) identified, on the basis of structural equations modelling (SEM), the following predictors of unfinished care - type of shift; work intensity (the MISSCARE Survey items); expected work load (the MISSCARE Survey items); communication problems (the MISSCARE Survey items), resources allocation; job satisfaction and intention of nurses to leave the job. The authors emphasize that unfinished care is most common in times of increased demands on care combined with a shortage of qualified staff. Bragadóttir and Kalisch (2018) compared the differences in perception of reasons between the practical and registered nurses. The differences were identified in material and human resources.

Foreign studies also compared differences in reasons for unfinished nursing care between so-called Magnet and non-Magnet hospitals (Kalisch and Lee, 2012). The status of the Magnet hospital is acquired by hospitals through an accreditation programme to recognize the magnetism of hospitals, i.e. Magnet Recognition Program ${ }^{\circledR}$. It is currently the most prestigious recognition that a healthcare organization can receive in terms of providing, excellence and innovations in professional nursing practice. Attractive, Magnet hospitals are characterized by a higher nurse-patient ratio, clinical autonomy, nursing practice supervision, supportive work environment, strong administrative and organization support (Aiken et al., 2018; Trinkoff et al., 2010). Results of surveys that compared hospitals with and without the magnet hospital status confirm that the prevalence of the missed nursing care is lower in Magnet hospitals, despite the fact that the differences in the number of nurses were not significant in terms of the type of hospital. An interesting finding was that nurses from non-Magnet hospitals perceived human resources and communication as more important reasons for missed nursing care. These results suggest significant implications for the hospital management, i.e. that the staff numbers are important, however, it is not the only component necessary to reach excellence in nursing care. The implementation of the evidence-based principles of the international accreditation programme Magnet Recognition Program ${ }^{\circledR}$ can also be inspiring for European hospitals in the area of developing a supportive work environment for nurses, increasing the safety culture, or the overall organization structure of hospitals. The analysis of the reasons contributing to the prevalence of missed nursing care can provide a broader view of the phenomenon, better understand the main barriers in providing complex nursing care, and particularly direct the decisions on further interventions (Bassi et al., 2020).

\section{Limitations}

The results of the study cannot be generalized for the entire population of Czech nurses as the nurses were not randomly selected for the research sample; the data collection took place within hospitals of the Czech region. As a part of the study, it was planned that the data would be collected by December 2020 to obtain important data for the observation of how the current epidemiological situation affected the problem of missed nursing care. However, with the critical development of the pandemic in individual Czech regions, the increase of hospitalized patients and the burden on nurses in hospitals, we terminated the data collection prematurely in October. The results, therefore, do not reflect the situation in Czech hospitals during the second wave of the pandemic, but instead reflect the time between the first and the second wave.

\section{Conclusions}

Insufficient staff associated with an unexpected increase in the number or severity of patients' conditions on wards were perceived to be the most significant reasons for omitting the nursing activities. Human and material resources were more significant reasons for general and practical nurses working in regional hospitals, compared to nurses working in university hospitals. There was a negative correlation proved between nurses' satisfaction with their current position, with the role of a nurse, with teamwork at the workplace and perception of reasons for missed nursing care. In further studies, we recommend focusing on process aspects (priority setting, options for nurses to be supervised, involving patients and caretakers) of the missed nursing care phenomenon. A deeper analysis of processes contributing to the prevalence of missed nursing care could help better understand the barriers of providing the complex nursing care and subsequently implement the effective interventions in practise.

\section{Author contributions}

EG, DB, DCH, ML: Made substantial contributions to the conception and design, or acquisition of data, or analysis and interpretation of data. EG, ZM, DB: Involved in drafting the manuscript and critically revising it for important intellectual content; gave final approval of the version to be published. Each author has participated sufficiently in the work to take public responsibility for appropriate portions of the content; and has agreed to be accountable for all aspects of the work in ensuring that questions related to the accuracy or integrity of any part of the work are appropriately investigated and resolved.

\section{Ethical considerations}

The research protocol was approved by the Ethical committee of the Faculty of Health Sciences of Palacký University Olomouc.

\section{Conflict of interests}

The authors declare no potential conflict of interests with respect to the research, authorship and/or publication of this article.

\section{Acknowledgements}

This article is based upon work from Grant IGA Unfinished nursing care and practice working environment (IGA FZV_2020_001). 


\section{Důvody nedokončené ošetřovatelské péče z pohledu sester z okresních a fakultních nemocnic}

\section{Souhrn}

Cíl: Hlavním cílem práce bylo zjistit rozdíly v důvodech nedokončené ošetřovatelské péče podle typu nemocnic a oddělení. Součástí práce bylo také zjistit souvislost mezi důvody nedokončené ošetřovatelské péče a pracovní spokojeností sester.

Dizajn: Průřezová korelační studie.

Metody: Soubor tvořilo 371 sester pracujících v interních a chirurgických oborech vybraných čtyř nemocnic v Olomouckém kraji. Na sběr dat byla použita česká verze dotazníku MISSCARE Survey, která obsahuje 61 položek rozdělených do tří oblastí - pracovní charakteristiky, nedokončená péče a důvody nedokončené péče. Důvody nedokončené ošetřovatelské péče byly v MISSCARE Survey operacionalizované doménami - lidské zdroje, materiální zdroje a komunikace. Sběr dat probíhal v období květen až záŕí 2020. Při analýze dat byly použity testy ANOVA a Pearsonův korelační koeficient.

Výsledky: Lidské zdroje, personální zabezpečení byly hodnocené jako nejvýznamnější důvody nedokončené ošetřovatelské péče. Statisticky významné rozdíly mezi fakultní nemocnicí a okresními nemocnicemi byly zjištěny v oblasti lidských a materiálních zdrojů. Pozitivní korelace byla zjištěna mezi počtem pacientů v poslední směně a významností důvodů v oblasti lidských zdrojů, materiálních zdrojů a komunikace, negativní korelace pak mezi spokojeností sester se současnou pozicí, s rolí sestry, s týmovou spoluprací na pracovišti a důvody nedokončené ošetřovatelské péče.

Závěr: Hlubší analýza procesů přispívajících k prevalenci chybějící ošetřovatelské péče může pomoci lépe pochopit bariéry poskytování komplexní ošetřovatelské péče a implementovat efektivní intervence do praxe.

Klíčová slova: akutní péče; důvody; chybějící ošetřovatelská péče; MISSCARE Survey; nástroj

\section{References}

1. Aiken LH, Sloane DM, Ball J, Bruyneel L, Rafferty AM, Griffiths P (2018). Patient satisfaction with hospital care and nurses in England: an observational study. BMJ Open 8(1): e019189. DOI: 10.1136/bmjopen-2017-019189.

2. Aiken LH, Sloane DM, Bruyneel L, Van den Heede K, Griffiths $P$, Busse R, et al. (2014). Nurse staffing and education and hospital mortality in nine European countries: a retrospective observational study. Lancet 383(9931): 1824-1830. DOI: 10.1016/S0140-6736(13)62631-8.

3. Ausserhofer D, Zander B, Busse R, Schubert M, De Geest S, Rafferty AM, et al. (2014). Prevalence, patterns and predictors of nursing care left undone in European hospitals: results from the multicountry cross-sectional RN4CAST study. BMJ Qual Saf 23(2): 126-135. DOI: 10.1136/bmjqs-2013-002318.

4. Bagnasco A, Aleo G, Timmins F, Begley T, Parissopoulos S, Sasso L (2017). The need for consistent family-centred support for family and parents of children admitted to paediatric intensive care unit. Nurs Crit Care 22(6): 327-328. DOI: $10.1111 /$ nicc.12327.

5. Ball JE, Bruyneel L, Aiken LH, Sermeus W, Sloane DM, Rafferty AM, et al. (2018). Post-operative mortality, missed care and nurse staffing in nine countries: A cross-sectional study. Int J Nurs Stud 78: 10-15. DOI: 10.1016/j.ijnurstu.2017.08.004.

6. Bassi E, Tartaglini D, Valpiani G, Grassetti L, Palese A (2020). Unfinished Nursing Care Survey: A development and validation study. J Nurs Manag 28(8): 2061-2071. DOI: 10.1111/ jonm.13170.

7. Blackman I, Henderson J, Willis E, Hamilton P, Toffoli L, Verrall C, et al. (2015). Factors influencing why nursing care is missed. J Clin Nurs 24(1-2): 47-56. DOI: 10.1111/jocn.12688.

8. Bragadóttir H, Kalisch BJ (2018). Comparison of reports of missed nursing care: registered nurses vs. practical nurses in hospitals. Scan J Caring Sci 32(3): 1227-1236. DOI: 10.1111/ scs.12570.

9. Bragadóttir H, Kalisch BJ, Smáradóttir SB, Jónsdóttir HH (2015). Translation and psychometric testing of the Icelandic version of the MISSCARE Survey. Scand J Caring Sci 29(3): 563-572. DOI: $10.1111 /$ scs.12150.

10. Cho E, Lee N-J, Kim E-Y, Kim S, Lee K, Park K-O, Sung YH (2016). Nurse staffing level and overtime associated with patient safety, quality of care, and care left undone in hospitals: A cross-sectional study. Int J Nurs Stud 60: 263-271. DOI: 10.1016/j.ijnurstu.2016.05.009.
11. Cho S-H, Kim Y-S, Yeon KN, You S-J, Lee ID (2015). Effects of increasing nurse staffing on missed nursing care. Int Nurs Rev 62(2): 267-274. DOI: 10.1111/inr.12173.

12. Dos Reis Dutra CK, Salles BG, de Brito Guirardello E (2019). Situations and reasons for missed nursing care in medical and surgical clinic units. Rev Esc Enferm USP 53: e03470. DOI: 10.1590/s1980-220x2017050203470.

13. Griffiths P, Recio-Saucedo A, Dall'Ora C, Briggs J, Maruotti A, Meredith P, et al. (2018). The association between nurse staffing and omissions in nursing care: A systematic review. J Adv Nurs 74(7): 1474-1487. DOI: 10.1111/jan.13564.

14. Henderson J, Willis E, Xiao L, Blackman I (2017). Missed care in residential aged care in Australia: An exploratory study. Collegian 24(5): 411-416. DOI: 10.1016/j.colegn.2016.09.001.

15. Jarošová $\mathrm{D}$, Zeleníková $\mathrm{R}$ (2017). Chybějící ošetřovatelská péče - MISSCARE CZ. Měřicí nástroje, dotazníky a manuály. Ostravská univerzita, Lékařská fakulta. [online] [cit. 2020-0122]. Available from: https://dokumenty.osu.cz/lf/uom/uompublikace/osetrovatelska-pece-a-pecovani/misscare-cz.pdf

16. John ME, Mgbekem MA, Nsemo AD, Maxwell GI (2016). Missed nursing care, patient outcomes and care outcomes in selected hospitals in Southern Nigeria. J Nurs Healthcare 1(2): 5.

17. Jones T, Willis E, Amorim-Lopes M, Drach-Zahavy A (2018). Advancing the science of unfinished nursing care: Exploring the benefits of cross-disciplinary knowledge exchange, knowledge integration and transdisciplinarity. J Adv Nurs 75(4): 905-917. DOI: $10.1111 /$ jan.13948.

18. Jones TL, Hamilton P, Murry N (2015). Unfinished nursing care, missed care, and implicitly rationed care: State of the science review. Int J Nurs Stud 52(6): 1121-1137. DOI: 10.1016/j. ijnurstu.2015.02.012.

19. Kalánková D, Bartoníčková D, Žiaková K (2019). Reasons for missed, rationed and unfinished nursing care. Ošetrovatel'stvo: teória, výskum, vzdelávanie 9 (2): 62-69. [online] [cit. 202001-22]. Available from: https://www.osetrovatelstvo.eu/ archiv/2019-rocnik-9/cislo-2/duvody-chybejici-pridelovane-anedokoncene-osetrovatelske-pece

20. Kalisch BJ, Lee KH (2012). Missed nursing care: Magnet versus non-Magnet hospitals. Nurs Outlook 60(5): e32-39. DOI: 10.1016/j.outlook.2012.04.006.

21. Kalisch BJ, Williams RA (2009). Development and psychometric testing of a tool to measure missed nursing care. J Nurs Adm 39(5): 211-219. DOI: 10.1097/NNA.0b013e3181a23cf5.

22. Kalisch BJ, Landstrom GL, Williams RA (2009). Missed nursing care: errors of omission. Nurs Outlook 57(1): 3-9. DOI: 10.1016/j.outlook.2008.05.007. 
23. Kalisch BJ, Terzioglu F, Duygulu S (2012). The MISSCARE Survey-Turkish: psychometric properties and findings. Nurs Econ 30(1): 29-37.

24. Kalisch BJ, Tschannen D, Lee KH (2011a). Do staffing levels predict missed nursing care? Int J Qual Health Care 23(3): 302-308. DOI: 10.1093/intqhc/mzr009.

25. Kalisch BJ, Tschannen D, Lee H, Friese CR (2011b). Hospital variation in missed nursing care. Am J Med Qual 26(4): 291-299. DOI: 10.1177/1062860610395929.

26. Maloney S, Fencl JL, Hardin SR (2015). Is nursing care missed? A comparative study of three North Carolina hospitals. Medsurg Nurs 24(4): 229-235.

27. Moreno-Monsiváis MG, Moreno-Rodríguez C, InterialGuzmán MG (2015). Missed Nursing Care in Hospitalized Patients. Aquichan 15(3): 318-328. DOI: 10.5294/ aqui.2015.15.3.2.

28. Schubert M, Ausserhofer D, Desmedt M, Schwendimann R, Lesaffre E, Li B, de Geest S (2013). Levels and correlates of implicit rationing of nursing care in Swiss acute care hospitals A cross sectional study. Int J Nurs Stud 50(2): 230-239. DOI: 10.1016/j.ijnurstu.2012.09.016.

29. Schubert M, Glass TR, Clarke SP, Aiken LH, Schaffert-Witvliet B, Sloane DM, de Geest S (2008). Rationing of nursing care and its relationship to patient outcomes: the Swiss extension of the International Hospital Outcomes Study. Int J Qual Health Care 20(4): 227-237. DOI: 10.1093/intqhc/mzn017.

30. Siqueira LDC, Caliri MHL, Kalisch B, Dantas RAS (2013). Cultural adaptation and internal consistency analysis of the MISSCARE Survey for use in Brazil. Rev Latino-Am Enfermagem 21(2): 610-617. DOI: 10.1590/S010411692013000200019.

31. Sist L, Contini C, Bandini A, Bandini S, Massa L, Zanin R, et al. (2017). MISSCARE Survey - Italian Version: findings from an Italian validation study. Ig Sanita Pubbl 73(1): 29-45.

32. Srulovici E, Drach-Zahavy A (2017). Nurses' personal and ward accountability and missed nursing care: A crosssectional study. Int J Nurs Stud 75: 163-171. DOI: 10.1016/j. ijnurstu.2017.08.003.

33. Trinkoff AM, Johantgen M, Storr CL, Han K, Liang Y, Gurses AP, Hopkinson S (2010). A Comparison of Working Conditions among Nurses in Magnet ${ }^{\circledR}$ and Non-Magnet ${ }^{\circledR}$ Hospitals. J Nurs Admin 40(7-8): 309-315. DOI: 10.1097/ NNA.0b013e3181e93719.

34. Vryonides S, Papastavrou E, Charalambous A, Andreou P, Merkouris A (2015). The ethical dimension of nursing care rationing: A thematic synthesis of qualitative studies. Nurs Ethics 22(8): 881-900. DOI: 10.1177/0969733014551377.

35. Willis E, Carryer J, Harvey C, Pearson M, Henderson J (2017). Austerity, new public management and missed nursing care in Australia and New Zealand. J Adv Nurs 73(12): 3102-3110. DOI: $10.1111 /$ jan.13380.

36. Zeleníková R, Gurková E, Jarošová D (2019). Missed nursing care measured by MISSCARE Survey - the first pilot study in the Czech Republic and Slovakia. Cent Eur J Nurs Midw 10: 958-966. DOI: 10.15452/CEJNM.2019.10.0002. 